\title{
20 Years of RET/PTC in Thyroid Cancer: Clinico-Pathological Correlations
}

\begin{abstract}
The RET/PTC oncogene has been isolated almost twenty years ago. During these years, the research has given a final answer to several questions. In fact, it has been demonstrated that: a) RET/PTC is an early event in the process of thyroid carcinogenesis and has a critical role in the generation of the papillary carcinoma; b) RET/PTC activation is essentially restricted to the papillary histotype and to the Hürthle thyroid tumors; c) its incidence increases after exposure to radiations. However, some questions have not found a final answer yet: a) which is the real frequency of RET/PTC activation? Likely it is around $20 \%$, but this point is still questionable; b) which other gene modifications are required to lead a thyroid cell carrying a RET/PTC oncogene to the malignant phenotype?, and c) is there any correlation between RET/PTC activation and clinical parameters? We hope that these questions will have a clear answer in the near future. (Arq Bras Endocrinol Metab 2007;51/5:731-735)
\end{abstract}

Keywords: Thyroid; Carcinoma; RET/PTC; Transformation

\section{RESUMO}

Vinte Anos de RET/PTC no Câncer de Tiróide: Correlações ClínicoPatológicas.

O oncogene RETPTC foi isolado há quase 20 anos atrás. Durante esses anos de pesquisa várias questões foram solucionadas. Na verdade, já foi demonstrado que: a) o RETPTC é um evento precoce no processo da carcinogênese da tiróide e tem um papel crítico na geração do carcinoma papilífero; b) a ativação do RETPTC está restrita essencialmente ao histotipo papilar e aos tumores de Hürthle; c) sua incidência aumenta após a exposição à radiação. Entretanto, algumas questões permanecem ainda sem uma resposta final: a) qual é a real freqüência de ativação do RETPTC? Provavelmente em torno de $20 \%$, mas este número ainda é questionável; b) quais outras modificações gênicas são necessárias para transformar uma célula tiroidiana que possui oncogene RETPTC no fenotipo maligno?; e c) existe alguma correlação entre a ativação do RETPTC e parametros clínicos? Esperamos que essas questões sejam solucionadas em futuro próximo (Arq Bras Endocrinol Metab 2007;51/5:731-735)

Descritores: Tireóide; Carcinoma; RET/PTC; Transformação

T 1987 , NATURE PUblished the first report of a new oncogene activated in human papillary thyroid carcinomas (PTC). The DNA extracted from the tumors of five PTC patients and from two corresponding lymphnodal metastases gave rise to transforming foci when transfected onto the murine NIH3T3 fibroblasts. Molecular analysis of the tertiary foci originating from these positive samples showed the same Alu pattern after digestion with restriction enzymes, indicating that the same oncogene was activated in all of the tumors positive at the transfection assay (1). After 3 years, this oncogene was molecularly cloned: it was a chimeric gene generated by the fusion of the RET tyrosine kinase domain (TK) with the 5' ter-

\section{revisõo}

\section{AlFREDO FusCO MASSIMO SANTORO}

Dipartimento di Biologia e Patologia Cellulare e Molecolare e/o Istituto di Endocrinologia ed Oncologia Sperimentale del CNR, Facoltà di Medicina e Chirurgia di Napoli, Università degli Studi di Napoli "Federico II", via Pansini, 5, 80131 Naples; e NOGEC (Naples Oncogenomic Center) - CEINGE,

Biotecnologie Avanzate-Napoli, \& SEMM - European School of Molecular Medicine, Naples Site, via Comunale Margherita, 482, 80145, Naples, Italy. 
minal region of a new gene that was denominated $\mathrm{H} 4$ (now CCDC6). This oncogene was denominated RET/PTC depending on the gene involved in this rearrangement and the thyroid cancer histotype from which it was isolated (2). In the following years, at least 10 types of RET/PTC variants have been isolated: all of them consist in the fusion of the TK domain of RET with other genes that provide to the chimeric gene the promoter and the 5' coding region (3). However, apart from RET/PTCl and RET/PTC3, all the other variants do not seem to have a significant role in PTCs since they have been isolated just in rare cases. In the case of RET/PTC3, the TK domain of RET is fused to the RFG gene (also designated Elel/ARA70/Ncoa4) (4). A chromosomal inversion [inv (10) (q11.2q21)] accounts for the generation of RET/PTCl (5), whereas a cytogenetically undetectable paracentric inversion within $10 \mathrm{q} 11.2$ accounts for the generation of the RET/PTC3 oncogene (3).

The inappropriate expression of RET/PTC in the thyroid follicular cells (where the RET protooncogene is not expressed), the mislocalization of the RET TK from the membrane to the cytoplasm, the absence the extracellular regulatory region of RET and the presence of coiled-coil domains in the RET-partner coding sequences, that favor the dimerization process, account for the oncogenic activity of the chimeric RET/ PTC gene.

After the identification and the cloning of the RET/PTC oncogene, several questions have been raised.

\section{IS RET/PTC INVOLVED IN THYROID CARCINO- GENESIS OR IS IT JUST AN ASSOCIATED EVENT?}

RET/PTC oncogene is able to transform the rat thyroid cells $\mathrm{PC} \mathrm{Cl} 3$ (3), which show all the typical markers of thyroid differentiation. In fact, the PC RET/ PTC cells change morphology, are no longer dependent on TSH for growth and lost all of their differentiated functions. However, they were not able to grow in soft agar and they were not tumorigenic when injected into athymic mice. This result is consistent with the low aggressiveness most frequently shown by human papillary carcinomas.

Moreover, transgenic mice expressing a TGmediated expression of RET/PTC oncogenes develop thyroid papillary carcinomas with features very similar to those shown by human PTCs with the presence of nuclear grooves and ground glass cells (6). Therefore, we can certainly assess that the RET/PTC oncogene has a critical role in thyroid carcinogenesis.

\section{IS RET/PTC ACTIVATION AN EARLY OR LATE EVENT IN THE PROCESS OF THYROID CARCINOGENESIS?}

The results obtained during these years clearly demonstrate that RET/PTC oncogene activation is an early event in the process of thyroid carcinogenesis. In fact, immunohistochemical and RT-PCR analyses first allowed the detection of RET/PTC activation in a high percentage of occult thyroid carcinomas (7). Moreover, RT-PCR analysis on the RNA extracted by Laser Capture Microdissection (LCM) from the papillary cells has allowed the detection of RET/PTC activation in thyroid nodules with incomplete morphological evidence of papillary carcinoma (8).

\section{WHICH IS THE PREVALENCE OF RET/PTC IN PAPILLARY THYROID CARCINOMAS, AND IS IT SPECIFIC FOR THIS TUMOR TYPE?}

Two studies have shown RET/PTCl rearrangements in hyalinizing trabecular variant of papillary carcinoma suggesting that this tumor represents a variant of papillary carcinoma rather than a separate entity (9). Conversely, almost all the data published so far exclude RET/PTC activation in adenomas, follicular carcinomas, and anaplastic thyroid carcinomas (ATC) (10).

Two different studies evidenced a significant number of RET/PTC activation, mainly RET/PTCl, in Hürthle thyroid cell adenomas and carcinomas, characterized by the presence of oncocytes (also called Askanazy or oxyphil cells), but not in Hürthle hyperplastic nodules $(3,11)$. The absence of RET/PTC activation in Hürthle hyperplastic lesions suggests that RET/PTC activation might represent a secondary event in the generation of Hürthle neoplasms.

A long-standing controversy exists with respect to the prevalence of RET/PTC in papillary thyroid carcinomas. Indeed, the reported frequency of RET/ PTC in papillary carcinomas in different studies varies from 0 to $87 \%$ (12). In part this is likely due to geographic variability. However, this cannot serve as the only explanation since a striking variability in the frequency has been reported in the same geographical regions ( 8 and 85 in Australia, 5 and 22 in Canada). In the USA, the five largest series report the frequency of RET/PTC ranging from 11 to $43 \%$ (12).

It is very interesting the work that has been recently done by the group of Nikiforov analyzing the same tumors with five different techniques. Accordingly to their data, it is likely that a "low-sensitive" 
RT-PCR and Southern blot are the most reliable techniques to detect RET/PTC activation. By the use of these techniques the cases of PTC positive for RET/PTC are about 20\% (12). This result is consistent with that reported by Santoro et al. (13).

Several reports have described multiple activation of the RET/PTC isoforms in the same patient. These findings are more frequent in radiation-induced tumors. These results would account for a plurifocal origin of thyroid papillary carcinomas occurring in genetically predisposed individuals. Alternatively, RET/PTC may also be in several cases a common secondary event in the process of thyroid carcinogenesis.

\section{DOES RET/PTC ACTIVATION OCCUR IN NON-THYROID NEOPLASIAS? AND WHY DOES IT OCCUR JUST IN THE THYROID?}

The results obtained so far seem to exclude the presence of RET/PTC in the neoplasias of tissues other than thyroid, at least in a significant number of cases. In fact, the analysis of more than five hundred tumors of different origin for RET/PTC activation gave negative results. Moreover, in the period ranging between 1980 and 1990, a huge number of DNAs originating from different neoplasias has been analyzed by many laboratories around the world, in a NIH3T3 transfection assay: there has not been any report of RET/PTC activation in non-thyroid neoplastic tissues. The group of Nikiforov proposed a possible explanation for this thyroid specificity. This group showed that, while RET and H4 loci are about 30 megabases apart in the linear map of chromosome 10, they frequently juxtapose in nuclei of thyroid cells but not in other cell types. This contiguity would provide the structural basis for the nonhomologous recombination of the two genes (14).

\section{IS RET/PTC ACTIVATION ASSOCIATED WITH RADIATION EXPOSURE?}

A sharp increase in the incidence of pediatric thyroid papillary cancer with a high prevalence of the solid-follicular tumors was documented after the Chernobyl power plant explosion. All of the studies performed analyzing these PTCs show a strong correlation between the solid variant PTC and the RET/PTC3 activation $(3,16)$. This result has been confirmed by transgenic RET/PTC3 mice: they develop PTCs with solid features (3). It is also noteworthy that a signifi- cantly higher prevalence of RET/PTC3 activation was observed in the most heavily contaminated areas suggesting a preferential formation of this type of rearrangement after high radiation doses. The analysis of PTC, which developed after a long latency period in Belarusian children showed a 1:1 ratio of RET/PTC3 and RET/PTCl. This suggests that RET/PTC3 may be typical for radiation-associated childhood PTC with a short latency period, whereas RET/PTCl may be a marker for later-occurring PTC of radiation-exposed adults and children (17). Two different studies performed in France and the USA on radiation-associated thyroid tumors originated after therapeutic radiations show RET/PTC rearrangements at a very high rate. However, in contrast with the radiation-associated tumors originated from the atomic accident of Chernobyl, the most frequently detected chimeric gene was RET/PTCl instead of the RET/PTC3 (3).

\section{IS RET/PTC ACTIVATED IN HASHIMOTO'S THYROIDITIS?}

Two studies have shown RET/PTCl activation in a significant number of Hashimoto's thyroiditis (HT) cases, whereas another study detected no RET rearrangements in Hashimoto's (18). Another group describes RET/PTC rearrangement in non-malignant thyroid tissue associated to lymphocytic thyroiditis (LT), whereas it was absent in the pure LT areas. A very recent study shows that sixty-eight percent (15 of 22) of HT were positive by FISH analysis (19).

Therefore, the activation RET/PTC in HT is still controversial. In our opinion it does not appear unexplainable: a RET/PTC activation in thyroid cells would not be able to induce the malignant phenotype in these cells. However, the presence of RET/PT cells might be able to evoke a strong immunological response. A secondary molecular event, that means another gene alteration, could determine the appearance of the thyroid cancer. This hypothesis seems supported by the presence of lymphoid infiltration in thyroids of transgenic mice carrying the RET/PTC oncogenes. An alternative hypothesis may be that free radicals production, cytokine secretion, cellular proliferation and other events related to the HT inflammation trigger the occurrence of the RET/PTC rearrangement in follicular cells "predisposed" to it by an unstable chromatin conformation. Similar mechanisms may underlie the occurrence of a low level of RET rearrangements as a secondary phenomenon in papillary carcinoma subsets. 


\section{DOES RET/PTC ACTIVATION CORRELATE WITH SOME CLINICAL DATA?}

Several studies have tried to associate the presence of a rearranged RET with clinical parameters. Some studies have found a certain tendency of the association of RET/PTC activation with lymphatic involvement in otherwise low-risk patients of young age, lower recurrence rate and improved survival with small tumors (3). Another study by Puxeddu et al. (20) did not show any correlation between RET/PTC activation and age, sex, tumor size, staging, number of neoplastic foci, and histological subtype. It is likely that these studies have been all impaired by the lack of a unique and validated technique to detect RET/PTC rearrangements.

\section{WHICH GENE ALTERATIONS ASSOCIATE TO RET/PTC TO ACHIEVE THE COMPLETE MALIGNANT PHENOTYPE IN HUMANS?}

This question does not have any answer yet. The model of the RET/PTC transgenic mice suggests that other gene alterations are involved in the process of the RET/PTC-induced carcinogenesis. In fact, thyroid neoplasias do not occur in all of the RET/PTC transgenic animals, and they appear only after long latency period (7-10) months, and not all the thyroid cells go towards the neoplastic phenotype. This clearly means that other molecular events are required for the development of thyroid carcinomas.

\section{CONCLUSIONS}

RET/PTC activation represents a feature of a significant number of PTC where it represents in most of the cases a very early event, with no or very low incidence in adenomas, follicular and anaplastic carcinomas. Transgenic animal models clearly support a critical role of RET/PTC in the process of thyroid carcinogenesis. Even though several isoforms of RET/PTC have been found, RET/PTCl and RET/PTC3 are the most frequent forms, prevailing the first in the classical papillary subtype, the second in the solid subtype. The RET/PTC activation has been found also in Hürthle adenomas and carcinomas, where it may represent, at odds with PTC, a secondary event. No clear association has been found between RET/PTC activation and clinical features, likely because of the lack of a unique and validated technique to detect RET/PTC rearrangements.

\section{ACKNOWLEDGEMENTS}

We apologize to the many colleagues whose work has not been cited here because of space limits. This work was supported by grants from the Associazione Italiana per la Ricerca sul Cancro (AIRC), the Ministero dell'Università e della Ricerca Scientifica e Tecnologica (MIUR), NOGEC-Naples Oncogenomic Center. We thank the Associazione Partenopea per le Ricerche Oncologiche (APRO) for its support.

\section{REFERENCES}

1. Fusco A, Grieco $M$, Santoro $M$, Berlingieri MT, Pilotti $S$, Pierotti MA, et al. A new oncogene in human thyroid papillary carcinomas and their lymph-nodal metastases. Nature 1987;328:170-3.

2. Grieco $M$, Santoro $M$, Berlingieri MT, Melillo RM, Donghi R, Bongarzone I, et al. PTC is a novel rearranged form of the RET proto-oncogene and is frequently detected in vivo in human thyroid papillary carcinomas. Cell 1990;60:557-63.

3. Santoro M, Melillo RM, Fusco A. RET/PTC activation in papillary thyroid carcinoma. Eur J Endocrinol 2006;155:645-53.

4. Santoro M, Dathan NA, Berlingieri MT, Bongarzone I, Paulin C, Pierotti MA, et al. Molecular characterization of RET/PTC 3: a novel rearranged version of the RET proto-oncogene in a human thyroid papillary carcinoma. Oncogene 1994;9:50916.

5. Pierotti MA, Santoro M, Jenkins RB, Sozzi G, Bongarzone I, Grieco M, et al. Characterization of a chromosome $10 q$ inversion juxtaposing RET and $\mathrm{H} 4$ genes and creating the oncogenic sequence PTC. Proc Natl Acad Sci USA 1991;89:1616-20.

6. Santoro M, Chiappetta G, Cerrato A, Salvatore D, Zhang L, Manzo G, et al. Development of thyroid papillary carcinomas secondary to tissue-specific expression of the RET/PTC1 oncogene in transgenic mice. Oncogene 1996;12:1821-6.

7. Viglietto G, Chiappetta G, Martinez-Tello FJ, Fukunaga FH, Tallini G, Rigopoulou D, et al. RET/PTC oncogene activation is an early event in thyroid carcinogenesis. Oncogene 1995; 11:1207-10.

8. Fusco A, Chiappetta G, Hui P, Garcia-Rostan G, Golden L, Kinder BK, et al. Assessment of RET/PTC oncogene activation and clonality in thyroid nodules with incomplete morphological evidence of papillary carcinoma: a search for the early precursors of papillary cancer. Am J Pathol 2002;60:2157-67.

9. Papotti M, Volante M, Giuliano A, Fassina A, Fusco A, Bussolati $\mathrm{G}$, et al. RET/PTC activation in hyalinizing trabecular tumors of the thyroid. Am J Surg Pathol 2000;24:1615-21.

10. Tallini G, Santoro M, Helie M, Carlomagno F, Salvatore G, Chiappetta G, et al. RET/PTC oncogene activation defines a subset of papillary thyroid carcinomas lacking evidence of progression to poorly differentiated or undifferentiated tumor phenotypes. Clin Cancer Res 1998;4:287-94.

11. Chiappetta G, Toti P, Cetta F, Giuliano A, Pentimalli F, Amendola I, et al. The RET/PTC oncogene is frequently activated in oncocytic thyroid tumors (Hürthle cell adenomas and carcinomas), but not in oncocytic hyperplastic lesions. J Clin Endocrinol and Metab 2002;87:364-9.

12. Zhu Z, Ciampi R, Nikiforova MN, Gandhi M, Nikiforov YE. Prevalence of RET/PTC rearrangements in thyroid papillary carcinomas: effects of the detection methods and genetic heterogeneity. J Clin Endocrinol Metab 2006;91:3603-10.

13. Santoro M, Carlomagno F, Hay ID, Herrmann MA, Melillo RM, Bongarzone I, et al. RET oncogene activation in human thyroid neoplasms is restricted to the papillary carcinoma subtype. J Clin Invest 1992;89:1517-22. 
14. Nikiforova MN, Stringer JR, Blough R, Medvedovic M, Fagin JA, Nikiforov YE. Proximity of chromosomal loci that participate in radiation-induced rearrangements in human cells. Science 2000;290:138-41.

15. Klugbauer S, Lengfelder E, Demidchik EP, Rabes HM. High prevalence of RET rearrangement in thyroid tumors of children from Belarus after the Chernobyl reactor accident. Oncogene 1995; 11:2459-67.

16. Nikiforov $Y$, Rowland JM, Bove KE, Monfore Munoz H, Fagin JA. Distinct patterns of ret rearrangements in morphological variants of radiation-induced and sporadic thyroid papillary carcinomas in children. Cancer Res 1997:57:1690-4.

17. Smida J, Salassidis K, Hieber L, Zitzelsberger H, Kellerer AM, Demidchik EP, et al. Distinct frequency of ret rearrangements in papillary thyroid carcinomas of children and adults from Belarus. Int J Cancer 1999:80:32-8.

18. Nikiforova MN, Caudill CM, Biddinger P, Nikiforov YE. Prevalence of RET/PTC rearrangements in Hashimoto's thyroiditis and papillary thyroid carcinomas. Int J Surg Pathol 2002;10:15-22.
19. Rhoden KJ, Unger K, Salvatore G, Yilmaz Y, Vovk V, Chiappetta $G$, et al. RET/papillary thyroid cancer rearrangement in nonneoplastic thyrocytes: follicular cells of Hashimoto's thyroiditis share low-level recombination events with a subset of papillary carcinoma. J Clin Endocrinol Metab 2006;91:2414-23.

20. Puxeddu E, Moretti S, Giannico A, Martinelli M, Marino C, Avenia N, et al. Ret/PTC activation does not influence clinical and pathological features of adult papillary thyroid carcinomas. Eur J Endocrinol 2003;148:505-13.

\section{Address for correspondence:}

Alfredo Fusco

Dipartimento di Biologia e Patologia Cellulare e Molecolare Facoltà di Medicina e Chirurgia di Napoli

via Pansini 5, 80131 Napoli, Italy

Fax: (39-081) 746-3037

E-mail: afusco@napoli.com 